\section{Australian Journal of \\ Crop Science}

AJCS 14(02):244-249 (2020)

doi: 10.21475/ajcs.20.14.02.p2006

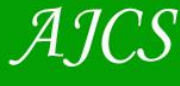

ISSN:1835-2707

\title{
Cadmium, copper, and chromium levels in maize plants and soil fertilized with sewage sludge
}

\author{
Iolanda Maria Soares Reis ${ }^{1 *}$, Suelen Cristina Nunes Alves ${ }^{2}$, Wanderley José de Melo ${ }^{2}$, Laércio Santos \\ Silva $^{2}$, Ludmila de Freitas ${ }^{3}$, Ivanildo Amorim de Oliveira ${ }^{3}$, Ianna Bizerra Barros ${ }^{4}$, Gabriel Maurício Peruca \\ de Melo ${ }^{5}$, Valéria Peruca de Melo ${ }^{5}$
}

'Teacher of Institute of Biodiversity and Forests, Federal University of the West of Pará (IBEF / UFOPA), 68040-255, Santarém, Pará, Brazil

${ }^{2}$ Faculty of Agrarian and Veterinary Sciences, Paulista State University, FCAV/UNESP, Jaboticabal, São Paulo, Brazil

${ }^{3}$ Federal Institute of Education, Science and Technology of Pará, Breves, Pará, Brazil

${ }^{4}$ Department of Soils, Federal University of Viçosa, Viçosa, Minas Gerais, Brazil

${ }^{5}$ Federal University of São Carlos, São Carlos, São Paulo, Brazil

*Corresponding author: iolanda.reis@ufopa.edu.br

Abstract

The use of sewage sludge as fertilizer is a widespread practice. However, the presence of heavy metals and pathogens in sludge are a cause for concern. The objective of this study was to determine the levels of cadmium (Cd), copper $(\mathrm{Cu})$, and chromium ( $\mathrm{Cr}$ ) in leaves, aerial parts, and kernels of maize grown in red latosol that was fertilized with sewage sludge for 15 consecutive years. Metal concentrations in soil and kernel yield were also determined. A randomized block design was used, with five replicates and four treatments: $T_{1}$, mineral fertilization (control); $T_{2}$, application of sewage sludge at $5 \mathrm{Mg} \mathrm{ha}^{-1} ; \mathrm{T}_{3}$, application of sewage sludge at 10

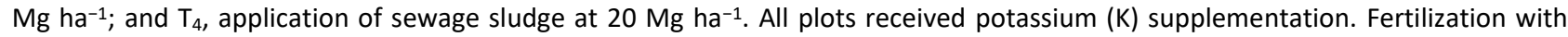
sewage sludge was as efficient as mineral fertilization. Sewage sludge had no negative effect on kernel yield. A negative correlation was observed between metal concentrations in soil and plant samples. $\mathrm{Cd}$ was detected at $\leq 0.04 \mathrm{mg} \mathrm{kg}^{-1}$ in kernels and $\mathrm{Cu}$ at $\leq 2.34$ $\mathrm{mg} \mathrm{kg}^{-1}$, whereas $\mathrm{Cr}$ was not detected in any sample. These levels are considered safe for human consumption, according to the Brazilian Health Regulatory Agency. Fertilization with sewage sludge for 15 years did not increase $\mathrm{Cu}, \mathrm{Cd}$, and $\mathrm{Cr}$ levels in the soil and had no negative effect on maize, which shows the potential of sewage sludge for agricultural use.

Keywords: Bioaccumulation; Heavy metal; Pollution; Productivity; Soil science.

Introduction

The agricultural use of sewage sludge is a widespread, feasible practice. It allows for sustainable management of sludge and increases the content of organic matter and nutrients, such as phosphorus $(\mathrm{P})$ and nitrogen $(\mathrm{N})$, in the soil (Merlino et al., 2010; Nogueira et al., 2010; Bueno et al., 2011; Silva et al., 2016, Costa et al., 2017; Melo et al., 2018). However, there are concerns regarding the presence of pathogens and heavy metals in sludge, which can leach into the water table or be absorbed by plants and transferred through the trophic chain, resulting in serious damage to human health (Mcbride, 1995; Lee et al., 2006; Costa et al., 2017). Not only the presence but also the accumulation of heavy metals, such as cadmium (Cd), chromium ( $\mathrm{Cr}$ ), copper, (Cu), nickel (Ni), lead, and zinc, in soils may result from fertilization with sewage sludge, especially that obtained from industrial sewage (Krebs et al., 1998).

The concentration of chemical elements in plants depends on the type of soil, plant species, plant maturation stage, crop management practices, and climate (McDowell et al., 1993). Exposure time, metal species, and absorption potential of the plant are important factors that also influence the level of contamination by heavy metals in crops (Mengel and Kirkby, 1987; Alloway, 1995).

Plants take up heavy metals via soil solution (Ali et al., 2013) and may distribute them to various organs (Dowswell et al., 1996; Amusan et al., 2005; Singh et al., 2010). The composition of this soil fraction depends on soil management practices and physicochemical characteristics of the soil (Gupta et al., 2014). Trace concentrations of heavy metals are naturally present in soil and do not pose a risk to the environment or to living beings. However, the same cannot be said for high concentrations of heavy metals, which are increased by anthropogenic actions, such as mining, waste disposal, deposition, and intense agricultural activity (Peris et al., 2007).

Various studies in Brazil and in other countries reported an association between successive applications of sewage sludge and the presence of heavy metals in the soil and in crops, especially maize (Oliveira et al., 2005; Merlino et al., 2010; Nogueira et al., 2010; McBride, 1995; Kabata-Pendias and Pendias, 2001). Although accumulation of heavy metals in plants may occur without apparent toxicity symptoms or 
yield loss (Jeevan Rao and Shantaran, 1996), it can affect the environment, food quality, and human health (Lee et al., 2006, Luo et al., 2007). Thus, it is important to evaluate the environmental impact of the use of sewage sludge in agricultural soils.

In this study, we determined the contents of $\mathrm{Cd}, \mathrm{Cu}$, and $\mathrm{Cr}$ in diagnostic leaves, aerial parts, and kernels of maize grown in red latosol fertilized with sewage sludge for 15 years. Kernel yield and heavy metal concentrations in soil were also determined.

\section{Results and discussion}

\section{Kernel yield}

Table 1 shows that soils treated with mineral fertilizer or different doses of sewage sludge showed similar physicochemical characteristics, differing only in $\mathrm{pH}$, which had no effect on yield. Kernel yield (9.04-10.21 Mg ha-1) did not differ significantly among treatments (Fig. 1) and was higher than the 2011/2012 national average (CONAB, 2013). In previous studies carried out in the same experimental area, the yield of maize crops fertilized with sewage sludge was similar to that of crops treated with mineral fertilizer (Nogueira et al., 2010).

Sewage sludge increases organic matter and $\mathrm{N}$ availability in the soil, which can explain why its efficiency was similar to that of mineral fertilizer. In the present study, sewage sludge was enriched with potassium (K), as sludge is a poor source of this nutrient (Barbosa et al., 2007).

Soil physical, chemical, and biological attributes in agricultural, forest, recreation, and restoration areas were improved by sewage sludge application (Nogueira et al., 2010; Zornoza et al., 2012). These improvements were attributed to the increase in organic matter. Antolin et al. (2005) also observed an improvement in soil chemical quality with sewage sludge application.

The agricultural use of sewage sludge increased the productivity of several crops. Behling et al. (2009) observed an increase of $1.224 \mathrm{~kg} \mathrm{ha}^{-1}$ in the yield of soybean fertilized with sewage sludge. Albuquerque et al. (2015) reported that sunflower yield increased with sewage sludge dose. Higgins (1994) and Rappaport et al. (1988) treated red latosol with 20 to $80 \mathrm{Mg} \mathrm{ha}^{-1}$ of sewage sludge for 4 years and observed a linear increase in maize yield with sewage sludge fertilization. In a study by Merlino et al. (2010), higher maize productivity was achieved with long-term use of sewage sludge in comparison with mineral fertilizer.

\section{$\mathrm{Cd}, \mathrm{Cu}$, and $\mathrm{Cr}$ concentrations in leaves, aerial parts, and kernels}

$\mathrm{Cd}$ concentrations in leaves were low $\left(0.11\right.$ to $\left.0.13 \mathrm{mg} \mathrm{kg}^{-1}\right)$ and did not differ between treatments (Table 2). As Cd is highly mobile, a low concentration of this metal in leaves suggests low soil availability. Similar results were reported by Merlino et al. (2010), who found no increase in Cd leaf concentrations in maize crops grown in soil treated with sewage sludge. Junio et al. (2011) reported that Cd levels were low in soils fertilized with sewage sludge or natural phosphate and undetectable in leaves of maize grown in these soils.
$\mathrm{Cu}$ contents in leaves were also low (3.55 to $4.58 \mathrm{mg} \mathrm{kg}^{-1}$ ) and showed no differences between treatments (Table 2). Maize plants were, in fact, moderately deficient in $\mathrm{Cu}$, which may be justified by the low mobility of this element (Seidel et al., 2009). Similar results were reported by Merlino et al. (2010) and Junio et al. (2011).

Concentrations of $\mathrm{Cd}$ and $\mathrm{Cu}$ in aerial parts did not differ between treatments. $\mathrm{Cd}$ levels varied from 0.03 to $0.04 \mathrm{mg}$ $\mathrm{kg}^{-1}$, and $\mathrm{Cu}$ levels from 2.98 to $3.23 \mathrm{mg} \mathrm{kg}^{-1}$. Merlino et al. (2010) found similar whole-plant concentrations of these metals.

$\mathrm{Cd}$ is not essential for plant growth and can be toxic at high concentrations (Silva et al. 2016). For instance, Cunha et al. (2008) observed that soil Cd levels of 8.7 to $13.1 \mathrm{mg} \mathrm{kg}^{-1}$ were toxic to plants.

In maize kernels, $\mathrm{Cd}$ concentrations ranged from 0.01 to $0.03 \mathrm{mg} \mathrm{kg}^{-1}$ and $\mathrm{Cu}$ concentrations ranged from 1.12 to $2.34 \mathrm{mg} \mathrm{kg}^{-1}$. There were no significant differences between treatments. According to the standards of the Brazilian Health Regulatory Agency (ANVISA, 1965), Cd and Cu contents in kernels were within the acceptable limits for human consumption. The values were also within the recommended limits for silage and hay (Nogueira et al., 2010).

The analytical method used in the current study was not sensitive enough to detect low concentrations of $\mathrm{Cr}$, neither in leaves nor in kernels. Therefore, $\mathrm{Cr}$ concentrations are expressed as the limit of detection, $0.18 \mathrm{mg} \mathrm{kg}^{-1}$. It is important to note that this value is above the safe levels for human consumption $\left(0.10 \mathrm{mg} \mathrm{kg}^{-1}\right.$ ) (ANVISA, 1965). Merlino et al. (2010) also failed to detect $\mathrm{Cr}$ in maize kernels.

$\mathrm{Cd}$ and $\mathrm{Cu}$ accumulation was higher in diagnostic leaves than in kernels. Similar results were found by Wang et al. (1997) in their study of $\mathrm{Ni}$ accumulation in winter wheat crops following application of sewage sludge at $60 \mathrm{Mg} \mathrm{ha}^{-1}$.

\section{Correlations between $\mathrm{Cd}, \mathrm{Cu}$, and $\mathrm{Cr}$ concentrations in soil, leaves, and kernels}

Soil concentrations of $\mathrm{Cr}, \mathrm{Cu}$, and $\mathrm{Cd}$ were more strongly correlated with leaf concentrations than with kernel concentrations (Table 2). Negative correlations were observed between $\mathrm{Cr}$ concentrations in soil and those in leaves and kernels, $\mathrm{Cd}$ concentrations in soil and in leaves, and $\mathrm{Cu}$ concentrations in soil and in kernels. These results support that $\mathrm{Cr}$ and $\mathrm{Cd}$ are present in sewage sludge in forms not readily available for plant uptake (Gomes et al., 2006; Silva et al., 2016) or are immobilized in soil by the formation of organic complexes (Soares et al., 2001). Gomes et al. (2006) observed that $\mathrm{Cu}$ contents in maize kernels decreased with increasing sludge doses.

Correlations between $\mathrm{Cu}$ levels in soil and in leaves were positive, probably because of the high mobility of the metal. No correlations were found between $\mathrm{Cd}$ concentration in soil and kernels (Table 2). The lack of significant correlations is attributable to the slow transfer of $\mathrm{Cd}$ from roots and leaves to kernels (Corguinha et al. 2015), which is a beneficial property of maize crops because it prevents $\mathrm{Cd}$ from accumulating to toxic levels in edible parts of the plant. 
Table 1. Chemical characteristics of red latosol treated with sewage sludge for 14 consecutive years.

\begin{tabular}{|c|c|c|c|c|c|c|c|c|c|c|}
\hline \multirow{2}{*}{ Treatment } & \multirow{2}{*}{$\begin{array}{l}\text { Resin P (mg } \\
\left.\quad \mathrm{dm}^{-3}\right)\end{array}$} & \multirow{2}{*}{$\begin{array}{c}\text { OM } \\
\left(\mathrm{g} \mathrm{dm}^{-3}\right)\end{array}$} & \multirow{2}{*}{$\mathrm{pH}\left(\mathrm{CaCl}_{2}\right)$} & $\mathrm{K}^{+}$ & $\mathrm{Ca}^{2+}$ & $\mathrm{Mg}^{2+}$ & $\mathrm{H}+\mathrm{Al}$ & SB & CEC & \multirow{2}{*}{$\begin{array}{l}\text { CV } \\
(\%)\end{array}$} \\
\hline & & & & \multicolumn{6}{|c|}{$\left(\mathrm{mmol}_{\mathrm{c}} \mathrm{dm}^{-3}\right)$} & \\
\hline $\mathrm{T}_{1}$ & $100^{\mathrm{a}}$ & $26^{a}$ & $5.4^{a}$ & $4^{a}$ & $40^{a}$ & $17^{\mathrm{ab}}$ & $34^{b}$ & $61.0^{b}$ & $95^{a}$ & $64^{a}$ \\
\hline $\mathrm{T}_{2}$ & $34^{c}$ & $22^{b}$ & $5.1^{\mathrm{a}}$ & $2.6^{b}$ & $23^{c}$ & $15^{b}$ & $38^{b}$ & $40.6^{b}$ & $78.6^{d}$ & $52^{c}$ \\
\hline $\mathrm{T}_{3}$ & $86^{b}$ & $26^{a}$ & $5.2^{\mathrm{a}}$ & $3.1^{\mathrm{b}}$ & $28^{b}$ & $16^{a}$ & $38^{b}$ & $47.1^{\mathrm{a}}$ & $85.1^{c}$ & $55^{b}$ \\
\hline $\mathrm{T}_{4}$ & $88^{b}$ & $26^{a}$ & $4.7^{a}$ & $2.3^{\mathrm{b}}$ & $21^{d}$ & $13^{c}$ & $52^{a}$ & $36.3^{a b}$ & $88.3^{b}$ & $41^{d}$ \\
\hline $\mathrm{CV}$ & 3.97 & 4.87 & 4.09 & 19.67 & 6.26 & 8.13 & 4.91 & 9.75 & 2.04 & 2.34 \\
\hline
\end{tabular}

$\mathrm{a}, \mathrm{b}, \mathrm{c}, \mathrm{d}$ Means followed by the same letter do not differ significantly by Tukey's test at $\mathrm{P}<0.05$. $\mathrm{T}_{1}$, control (fertilized with NPK); $\mathrm{T}_{2}$, fertilized with sewage sludge at $5 \mathrm{Mg}$ $\mathrm{ha}^{-1} ; \mathrm{T}_{3}$, fertilized with sewage sludge at $10 \mathrm{Mg} \mathrm{ha}^{-1}$; and $\mathrm{T}_{4}$, fertilized with sewage sludge at $20 \mathrm{Mg} \mathrm{ha}^{-1}$. OM, organic matter; SB, sum of bases; CEC; cation-exchange capacity; and CV, coefficient of variation.

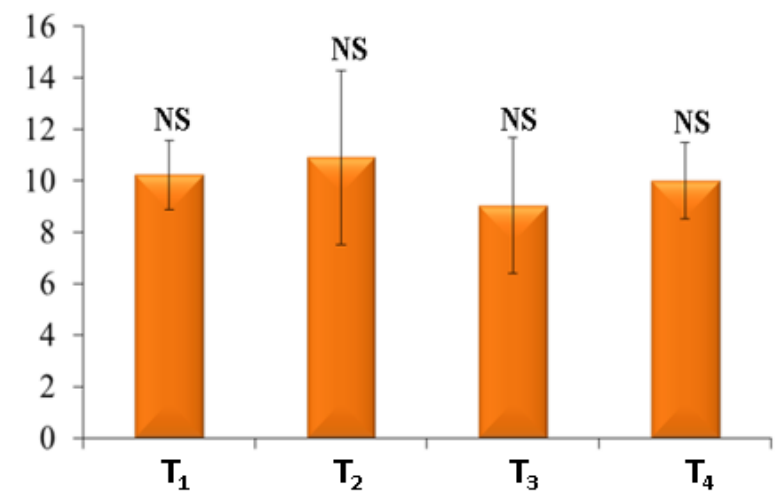

Fig 1. Kernel yield $\left(\mathrm{Mg} \mathrm{ha}^{-1}\right)$ of maize grown in soil fertilized with sewage sludge. $\mathrm{T}_{1}$, control (fertilized with NPK); $\mathrm{T}_{2}$, fertilized with sewage sludge at $5 \mathrm{Mg} \mathrm{ha}^{-1} ; \mathrm{T}_{3}$, fertilized with sewage sludge at $10 \mathrm{Mg} \mathrm{ha}^{-1}$; and $\mathrm{T}_{4}$, fertilized with sewage sludge at $20 \mathrm{Mg}^{-1}$. NS; not significantly different from control (Tukey's test; $P \geq 0.05$ ).

Table 2. Cadmium ( $\mathrm{Cd})$, copper $(\mathrm{Cu})$, and chromium $(\mathrm{Cr})$ contents $\left(\mathrm{mg} \mathrm{kg}^{-1}\right)$ in diagnostic leaves, aerial parts, and kernels of maize grown in red latosol treated with sewage sludge.

\begin{tabular}{|c|c|c|c|c|c|c|c|c|c|}
\hline \multirow{2}{*}{ Treatment } & \multicolumn{3}{|c|}{ Diagnostic leaf } & \multicolumn{3}{|c|}{ Aerial parts } & \multicolumn{3}{|l|}{ Kernel } \\
\hline & $\mathrm{Cd}$ & $\mathrm{Cu}$ & $\mathrm{Cr}^{*}$ & $\mathrm{Cd}$ & $\mathrm{Cu}$ & $\mathrm{Cr} *$ & $\mathrm{Cd}$ & $\mathrm{Cu}$ & $\mathrm{Cr}^{*}$ \\
\hline $\mathrm{T}_{1}$ & $0.11^{a}$ & $4.58^{a}$ & $<0.18$ & $0.04^{a}$ & $2.98^{a}$ & $<0.18$ & $0.01^{b}$ & $1.11^{\mathrm{a}}$ & $<0.18$ \\
\hline $\mathrm{T}_{2}$ & $0.12^{a}$ & $4.39^{a}$ & $<0.18$ & $0.03^{a}$ & $3.22^{\mathrm{a}}$ & $<0.18$ & $0.01^{b}$ & $2.34^{a}$ & $<0.18$ \\
\hline $\mathrm{T}_{3}$ & $0.13^{a}$ & $3.75^{a}$ & $<0.18$ & $0.03^{a}$ & $3.21^{a}$ & $<0.18$ & $0.02^{\mathrm{ab}}$ & $1.16^{a}$ & $<0.18$ \\
\hline $\mathrm{T}_{4}$ & $0.13^{a}$ & $3.55^{\mathrm{a}}$ & $<0.18$ & $0.04^{a}$ & $3.13^{a}$ & $<0.18$ & $0.03^{a}$ & $2.34^{\mathrm{a}}$ & $<0.18$ \\
\hline CV (\%) & 7.18 & 11.76 & - & 40.31 & 18.11 & - & 18.16 & 52.22 & - \\
\hline
\end{tabular}

$\mathrm{a}, \mathrm{b}$ Means followed by the same letter do not differ significantly by Tukey's test at $\mathrm{P}<0.05 .{ }^{*} \mathrm{Cr}$ levels were considered equal to the limit of detection $\left(0.18 \mathrm{mg} \mathrm{kg}^{-1}\right)$ for all samples. $\mathrm{T}_{1}$, control (fertilized with NPK); $\mathrm{T}_{2}$, fertilized with sewage sludge at $5 \mathrm{Mg} \mathrm{ha}^{-1} ; \mathrm{T}_{3}$, fertilized with sewage sludge at $10 \mathrm{Mg} \mathrm{ha}^{-1}$; and $\mathrm{T}_{4}$, fertilized with sewage sludge at $20 \mathrm{Mg}$ ha ${ }^{-1}$. OM, organic matter; SB, sum of bases; $\mathrm{CEC}$; cation-exchange capacity; and CV, coefficient of variation.

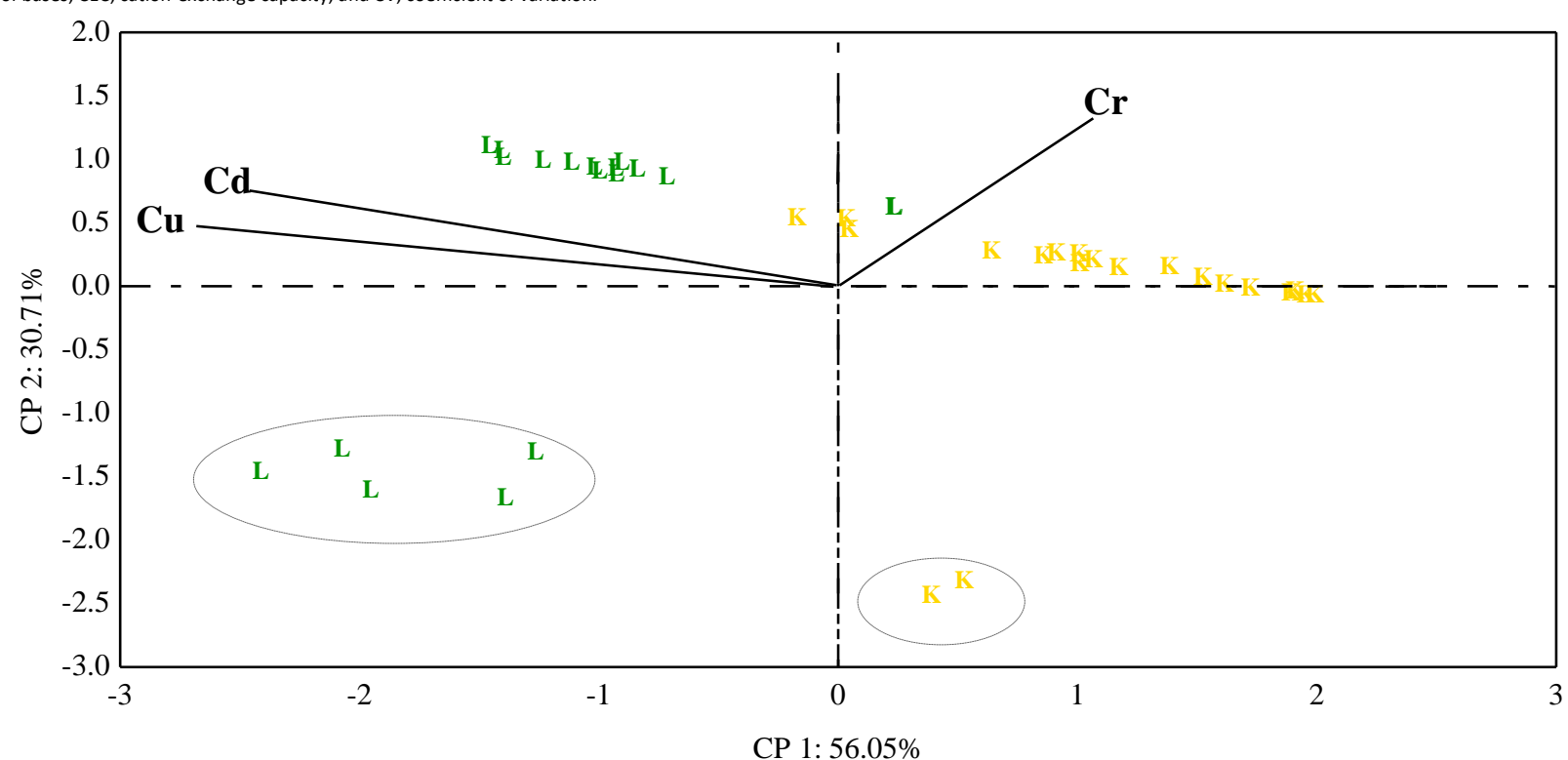

Fig 2. Principal component analysis (PCA) of cadmium (Cd), copper ( $\mathrm{Cu})$, and chromium ( $\mathrm{Cr}$ ) concentrations in maize leaves (L) and kernels (K). 
Table 3. Correlation coefficients between chromium ( $\mathrm{Cr}$ ), copper $(\mathrm{Cu})$, and cadmium $(\mathrm{Cd})$ contents in maize leaves, kernels, and soil sampled at different depths.

\begin{tabular}{|c|c|c|c|c|c|c|}
\hline & Leaf $\mathrm{Cr}$ & Leaf $\mathrm{Cu}$ & Leaf Cd & Kernel $\mathrm{Cr}$ & Kernel Cu & Kernel Cd \\
\hline \multicolumn{7}{|c|}{ Soil depth of 0.0 to $0.5 \mathrm{~m}$} \\
\hline Soil Cr & $-0.41 * *$ & $0.92 * *$ & $0.74^{* *}$ & $-0.48 * *$ & $0.48^{* *}$ & $-0.52 * *$ \\
\hline Soil Cu & $-0.41 * *$ & $0.85^{* *}$ & $0.62 * *$ & $-0.46 * *$ & $-0.03 * *$ & $-0.13^{* *}$ \\
\hline Soil Cd & $-0.66 * *$ & $-0.45^{* *}$ & $-0.72 * *$ & $-0.61^{* *}$ & $-0.76^{* *}$ & $0.89^{\text {ns }}$ \\
\hline \multicolumn{7}{|c|}{ Soil depth of 0.5 to $0.10 \mathrm{~m}$} \\
\hline Soil Cr & $-0.61 * *$ & $0.69 * *$ & $0.48 * *$ & $-0.67 * *$ & $0.65 * *$ & $-0.57^{* *}$ \\
\hline Soil Cu & $-0.92^{* *}$ & $0.39 * *$ & $0.04 * *$ & $-0.94 * *$ & $-0.02 * *$ & $0.13^{* *}$ \\
\hline Soil Cd & $-0.67^{* *}$ & $-0.52 * *$ & $-0.78^{* *}$ & $-0.61 * *$ & $-0.73^{* *}$ & $0.88^{\text {ns }}$ \\
\hline \multicolumn{7}{|c|}{ Soil depth of 0.10 to $0.20 \mathrm{~m}$} \\
\hline Soil $\mathrm{Cr}$ & $-0.51 * *$ & $0.87 * *$ & $0.65^{* *}$ & $-0.58 * *$ & $0.49 * *$ & $-0.49 * *$ \\
\hline Soil $\mathrm{Cu}$ & $-0.64 * *$ & $0.31 * *$ & $-0.01 * *$ & $-0.64 * *$ & $-0.53 * *$ & $0.52^{* *}$ \\
\hline Soil Cd & $-0.56 * *$ & $-0.68 * *$ & $-0.89 * *$ & $-0.49 * *$ & $-0.74 * *$ & $0.90^{\text {ns }}$ \\
\hline
\end{tabular}

$\mathrm{Cr}$ levels were considered equal to the limit of detection $\left(0.18 \mathrm{mg} \mathrm{kg}^{-1}\right)$ for all samples. $\mathrm{ns}$, not significant. ${ }^{* *}$ significant $1 \%$.

\section{Principal component analysis (PCA) of $\mathrm{Cd}, \mathrm{Cu}$, and $\mathrm{Cr}$ levels in leaves and kernels}

The results of $\mathrm{Cd}, \mathrm{Cu}$, and $\mathrm{Cr}$ accumulation in leaves and kernels were subjected to PCA (Fig. 2). Multivariate statistical techniques such as PCA are useful to interpret environmental data. For instance, they can help distinguish the presence of naturally occurring metals from the presence of metals brought about by anthropogenic activities (Micó et al., 2006; Navee Dullah et al., 2013; Sun et al., 2013; Parelho et al., 2014; Silva et al., 2016). This differentiation is important to compare metal concentrations present in sludge, soil, and plant samples with reference levels for groundwater and agricultural plants.

Principal component 1 (PC1) and principal component 2 (PC2) explained together $86.76 \%$ of the total variance of the dataset (PC1, 56.05\%; PC2, 30.71\%). PC1 showed that diagnostic leaves had the highest $\mathrm{Cd}$ and $\mathrm{Cu}$ concentrations, followed by aerial parts and kernels. $\mathrm{Cr}$ concentrations in all samples were considered equal to the detection limit and therefore cannot be compared.

PC2 showed that $\mathrm{Cd}$ and $\mathrm{Cu}$ were prone to accumulate in leaves. This is in agreement with the findings of Costa et al. (2007) regarding the transfer of heavy metals from soil to soybean and rice grains. However, in the current study, Cd and $\mathrm{Cu}$ accumulation was not sufficient to reach toxic levels, indicating that use of K-enriched sewage sludge does not lead to unacceptable concentrations of $\mathrm{Cd}, \mathrm{Cu}$, and $\mathrm{Cr}$ in plants for human consumption or other purposes (ANVISA, 1965).

\section{Materials and methods}

\section{Experiment location}

The experiment was performed at the Experimental Farm of the São Paulo State University, Jaboticabal, Brazil (21 $1^{\circ} 15^{\prime} 22^{\prime \prime} \mathrm{S}, 48^{\circ} 15^{\prime} 18^{\prime \prime} \mathrm{W}, 618 \mathrm{~m}$ above sea level). In $1997 / 98$, an experimental plot with eutrophic red latosol began to be treated with sewage sludge. The treatment was maintained for 15 consecutive years.

In the first year, treatments consisted of fertilization with 2.5, 5.0, and $10.0 \mathrm{Mg} \mathrm{ha}^{-1}$ of sewage sludge on a dry basis. The control, $T_{1}$, consisted of mineral fertilization.

From the second year onward, mineral fertilization $\left(T_{1}\right)$ was determined on the basis of soil analysis and recommendations for maize cultivation, according to Raij et al. (1996). From the fourth year onwards, plots receiving 2.5 $\mathrm{Mg} \mathrm{ha}^{-1}$ began to receive $20 \mathrm{Mg} \mathrm{ha}^{-1}$ of sewage sludge. A total of $0,75,150$, and $247.5 \mathrm{Mg} \mathrm{ha}{ }^{-1}$ of sewage sludge were applied during the 15 years of experiment to plots assigned to treatments $1,2,3$, and 4 , respectively.

\section{Experimental design and treatments}

In the 2011/12 agricultural year, corresponding to the 15th year since the beginning of soil treatment with sewage sludge, we carried out a randomized block design with four treatments and five repetitions. The treatments were as follows: $T_{1}$, mineral fertilization (control); $T_{2}, 5 \mathrm{Mg} \mathrm{ha}^{-1}$ sewage sludge; $T_{3}, 10 \mathrm{Mg} \mathrm{ha}^{-1}$ sewage sludge; and $\mathrm{T}_{4}, 20 \mathrm{Mg}$ $\mathrm{ha}^{-1}$ sewage sludge.

Soil samples (0.0-0.20 m depth) were collected from all treatment plots for analysis of soil fertility, which was determined according to the methods of Raij et al. (2001) (Table 1). $T_{1}$ (control) received fertilization with NPK, according to the recommendations of Raij et al. (1996) for the production of $80 \mathrm{~kg} \mathrm{ha}^{-1}$ maize.

Maize (Zea mays) was planted during the first 6 years of the experiment, followed by sunflower (Helianthus annuus) in the seventh year and crotalaria (Crotalaria juncea) in the eighth year. Maize was grown successively from the ninth year onwards.

The sewage sludge used during the 15th year of the experiment was obtained from the sewage treatment plant of the São Paulo State Water Sanitation Company (SABESP), Monte Alto, SP, Brazil. Sewage sludge contained 5.60, 246.65 , and $546.54 \mathrm{mg} \mathrm{kg}^{-1}$ of $\mathrm{Cd}, \mathrm{Cu}$, and $\mathrm{Cr}$, respectively, as determined by the United States Environmental Protection 
Agency (US EPA) method 3050 B (USEPA, 1996). These levels are within the limits allowed for agricultural use of sewage sludge, according to CONAMA Resolution no. 375 (2006). Sewage sludge was broadcast and incorporated into the soil with a disc harrow. After sludge application, the field was furrowed at distances of $0.9 \mathrm{~m}$, and control plots $\left(T_{1}\right)$ were fertilized with ammonium sulfate and potassium chloride ( $\mathrm{KCl}) . \mathrm{T}_{2}, \mathrm{~T}_{3}$, and $\mathrm{T}_{4}$ plots were fertilized with $\mathrm{KCl}$ only.

Maize (Bt hybrid Impacto Viptera) seeds were sown after fertilization. When seedlings were about $0.2 \mathrm{~m}$ high, plants were thinned to 5-7 plants per meter. Sixty days after emergence (DAE), 10 soil samples were collected at three depth ranges each $(0.00-0.05,0.05-0.10$, and $0.10-0.20 \mathrm{~m})$. Samples were air dried, sieved through a $2 \mathrm{~mm}$ mesh, and subjected to chemical analysis.

\section{Determination of metal concentrations in soil and plant samples}

Maize leaves opposite and below the primary ear (diagnostic leaves) were harvested at $60 \mathrm{DAE}$. Aerial parts of 6 plants per treatment were cut close to the soil surface from two inner rows at 90 DAE. Cobs were harvested manually at 125 DAE from two inner rows, excluding $1 \mathrm{~m}$ from the edges of the plot. Moisture was adjusted to $13 \%$ for the calculation of kernel yield. Prior to metal determination, soil samples were digested with $\mathrm{HNO}_{3}$ in a microwave oven and plant samples were digested with a mixture of $\mathrm{HNO}_{3}, \mathrm{HCl}$, and $\mathrm{H}_{2} \mathrm{O}_{2}$ on a heating plate, according to US EPA methods 3051A and 3050B, respectively (USEPA, 1996). Cd, Cu, and $\mathrm{Cr}$ concentrations were determined by atomic absorption spectrophotometry using acetylene flame for $\mathrm{Cd}$ and $\mathrm{Cu}$ determination and acetylene-nitrous oxide flame for $\mathrm{Cr}$ determination. The limit of detection (LD) was calculated according to Giné-Rosias (1998).

\section{Statistical analysis}

Data were subjected to analysis of variance (ANOVA), and means were compared by Tukey's test at $P<0.05$. It was necessary to transform the data to a normal distribution using $V x$. After standardization $(\mu=0 ; \sigma=1)$, the data were subjected to a PCA. The number of retained components was determined using an eigenvalue of 1.00 and a cumulative variance of $70 \%$, according to Kaiser (1958). Statistical analyses were performed using Statistica 7.0 (StatSoft Inc., 2005).

\section{Conclusion}

Application of K-enriched sewage sludge had the same effect as mineral fertilization on maize kernel yield. Correlations between $\mathrm{Cd}, \mathrm{Cu}$, and $\mathrm{Cr}$ levels in soil and in plants were low in most cases. $\mathrm{Cd}$ and $\mathrm{Cu}$ contents in leaves and aerial parts of the plant were considered low and were not affected by sewage sludge doses.

\section{Acknowledgements}

We thank the Brazilian Coordination for the Improvement of Higher Education Personnel (CAPES) for the scholarship awarded to the first author.

\section{References}

Anvisa - Agência Nacional de Vigilância Sanitária Decreto no 55.871, 26/03/1965. Available online at:

<http://www.anvisa.gov.br/legis/decretos/55871_65.htm> (Accessed 20 january 2017).

Albuquerque HC, Junio GRZ, Sampaio RA, Fernandes LA, Zonta E, Barbosa CF (2015) Yield and nutrition of sunflower fertilized with sewage sludge. RevBrasEngAgrícAmbient.19:553-559.

Ali H, Khan E, Sajad MA (2013) Phytoremediation of heavy metals - Concepts and applications. Chemosphere. 91:869-881.

Antolin MC, Pascual I, Garcia C, Polo A, Sanchez DM (2005) Growth, yield and solute content of barley in soils treated with sewage sludge under semiarid Mediterranean conditions. Field Crop Res.94:224-237.

Amusan AA, Ige DV, Olawale R (2005) Characteristics of Soils and Crops' Uptake of Metals in Municipal Waste Dump Sites in Nigeria. J Hum Ecol. 17:167-171.

Barbosa GMC, Tavares Filho J, Brito OR, Fonseca ICB (2007) Efeito residual do lodo de esgoto na produtividade do milho safrinha. R Bras Ci Solo.31:601-605.

Behling $M$, Dias FC, Amaral Sobrinho NMB, Oliveira C, Mazur N (2009) Nodulação, acúmulo de nitrogênio no solo e na planta, e produtividade de soja em solo tratado com lodo de estação de tratamento de resíduos industriais. Bragantia.68:453-462.

Bueno JRP, Berton RS, Silveira APD, Chiba MK, Andrade CA, Maria IC (2011) Chemical and microbiological atributes of an oxisol treated with sucsessive applications of sewage sludge. R Bras Ci Solo. 35:1461-1470.

Companhia Nacional de Abastecimento - CONAB (2013) Acompanhamento da safra brasileira de grãos, Safra 2012/13 - Décimo levantamento, Brasília. Available online at:

<http://www.conab.gov.br/OlalaCMS/uploads/arquivos/13_ 07_09_09_04_53_boletim_graos_junho_2013.pdf>.

(Accessed 28 november 2016).

Conselho Nacionaldo Meio Ambiente - CONAMA (2006) Critérios e procedimentos, para o uso agrícola de lodos de esgoto gerados em estações de tratamento de esgoto sanitário e seus produtos derivados, e dá outras providências. Diário Oficial da União, Brasília. Available online

<http://www2.mma.gov.br/port/conama/res/res06/res37 506.pdf>. (Accessed 12 april 2019).

Corguinha APB, Souza GA, Gonçalves VC, Carvalho CA, Lima WEA, Martins FAD, Yamanaka $\mathrm{CH}$, Francisco $\mathrm{EAB}$, Guilherme LRG (2015) Assessing arsenic, cadmium, and lead contents in major crops in Brazil for food safety purposes. J Food Compos Anal. 37:143-150.

Costa RDS, Paula Neto P, Campos MCC, Nascimento WB, Nascimento CWA, Silva LS, Cunha JM (2007). Natural contents of heavy metals in soils of the southern Amazonas state, Brazil. Semina. 38:3499-3514.

Cunha KPV, Nascimento CWA, Pimentel RM, Accioly AMA, Silva AJ (2008) Disponibilidade, acúmulo e toxidez de cádmio e zinco em milho cultivado em solo contaminado. R Bras Ci Solo. 32:1319-1328.

Dowswell CR, Paliwal RL, Cantrell RP (1996) Maize in the Third World. Westview Press, Boulder. 
Giné-Rosias MF(1998) Espectrofotometria de emissão atômica com plasma acoplado indutivamente (ICP-AES). Piracicaba: CENA,

Gomes SBV, Nascimento CWA, Biondi CM, Accioly AMA (2006) Distribuição de metais pesados em plantas de milho cultivadas em Argissolo tratado com lodo de esgoto. Cienc Rural. 36:1689-1695.

Gupta DK, Chatterjee S, Datta S, Veer V, Walther C (2014). Role of phosphate fertilizers in heavy metal uptake and detoxification of toxic metals. Chemosphere. 108:134144.

Higgins AJ (1984) Land application of sewage sludge with regard to cropping systems and pollution potencial J Environ Qual. 13:441-448.

Jeevan Rao K, Shantaram MV (1996) Effect of urban solid wastes on dry matter yield, uptake of micronutrients and heavy metals by maize plants. J Environ Biol. 17:25-32.

Junio GRZ, Sampaio RA, Santos GB, Nascimento AL, Prates FBS, Fernandes LA (2011) Metais pesados em milho fertilizado com fosfato natural e composto de lodo de esgoto. R Bras Eng Agríc Ambiental. 15:1082-1088.

Kabata-Pendias A, Pendias H (2001) Trace elements in soil and plants. 3 ed. Boca Raton: CRC Press.

Kaiser HF (1958) The varimax criterion for analytic rotation in factor analysis. Psychometrika. 23:187-2000.

Krebs R, Gupta SK, Furrer G, Schulin R (1998) Solubility and plant uptake of metals with and without liming of sludgeamended soils. J Environ Qual. 27:18-23.

Lee CS, Li X, Shi W (2006) Metal contamination in urban, suburban, and country park soils of Hong Kong: A study based on GIS and multivariate statistics. Sci Total Environ. 356:45-61.

Luo W, Lu Y, Giesy JP, Wang T, Shi Y, Wang G, Xing Y (2007) Effects of land use on concentrations of metals in surface soils and ecological risk around Guanting Reservoir, China. Environ Geochem Health. 29: 459-471.

Mcbride MB (1995) Toxic metal accumulation from agricultural use of sludge: are USEPA regulations protective? J Environ Qual. 24:5-18.

Melo WJ, Delarica D, Guedes A, Lavezzo L, Donha R, Araújo A, Melo G, Macedo F (2018) Ten years of application of sewage sludge on tropical soil. A balance sheet on agriculture al crops and environmental quality. Sci Total Environ. 643:1493-1501.

Mcdowell LR., Conrad JH, Hembry FG (1993) Minerals for grazing ruminants in tropical regions. 2.ed. Gainesville:University of Florida.

Mengel K, Kirkby EA (1987) Principles of plant nutrition. 4.ed. Bern: International Potash Institute.

Merlino LCS, Melo WJ, Macedo FG, Guedes ACTP, Ribeiro MH, Melo VP, Melo GMP (2010) Bário, cádmio, cromo e chumbo em plantas de milho e em Latossolo após onze aplicações anuais de lodo de esgoto. R Bras Ci Solo. 34:2031-2039.

Micó C, Recatalá L, Peris M, Sánchez J(2006) Assessing heavy metal sources in agricultural soils of a European Mediterranean area by multivariate analysis. Chemosphere. 65: 863-872.

Navee Dullah N, Hashmi MZ, Yu C, Shen H, Duan D, Shen C, Lou L, Chen Y (2013) Risk assessment of heavy metals pollution in agricultural soils of siling reservoir watershed in Zhejiang province, China. Biomed Res Int. 2013:1-10.
Nogueira TAR, Melo WJ, Nogueira TAR, Fonseca IM, Marques MO, He ZL (2010) Barium uptake by maize plants as affected by sewage sludge in a long-term field study. J Hazard Mater. 181:1148-1157.

Oliveira KW, Melo WJ, Pereira GT, Melo VP, Melo GP (2005) Heavy metals in oxisols amended with biosolids and cropped with maize in a long-term experiment. Sci Agric. 62:381-388.

Parelho C, Rodrigues AS, Cruz JV, Garcia P (2014) Linking trace metals and agriculturalland use in volcanic soils: a multivariate approach. Sci Total Environ. 496: 241-247.

Peris M, Micó C, Recatalá L, Sánchez R, Sánchez J (2007) Heavy metal contents in horticultural crops of a representative area of the European Mediterranean region. Sci Total Environ. 378: 42-48.

Raij BV, Andrade JC, Cantarella H, Quaggio JA (2001) Análises químicas para avaliação da fertilidade de solos tropicais. Campinas: Instituto Agronômico.

Raij BV, Cantarella H, Quaggio JA, Furlani AMC (1996) Recomendações de adubação e calagem para o Estado de São Paulo. Campinas: IAC.

Rappaport BD, Martins DC, ReneauJunior RB, Simpson TW (1988) Metal availability in sludge-amended soils with elevated metal levels. J Environ Qual. 17:42- 47.

Seidel EP, Costa ACS, Lana MC (2009) Fitodisponibilidade de cobre e produção de matéria seca por plantas de milho em resposta à aplicação de dejetos de suínos. R Bras Ci Solo. 33:1871-1878.

Silva LS, Galindo ICL, Nascimento CWA, Gomes RP, Campos MCC, Freitas L, Oliveira IA (2016) Heavy metal contents in Latosols cultivated with vegetable crops. Pesq Agropec Trop. 46:391-400.

Singh A, Sharma RK, Agrawal M, Marshall FM (2010) Health Risk Assessment of Heavy Metals via Dietary Intake of Foodstuffs from the Wastewater Irrigated Site of a Dry Tropical Area of India. Food Chem Toxicol. 48: 611-619.

Soares CRFS, Grazziotti, PH, Siqueira JO, Carvalho JG, Moreira FMS (2001) Toxidez de zinco no crescimento e nutrição de Eucalyptus maculata e Eucalyptus urophylla em solução nutritiva. Pesq Agropec Bras.36:339-348.

Statistica (2005) Statistica 7.0, EUA Software. Tucksa: StatSof.

SUN G, Yao L, Jiao L, ShiY, Zhang O, Tao M, Shan G, He Y (2013) Characterizing PM2.5 pollution of asubtropical metropolitan area in China. Atmosp Clim Sciences. 3:100110.

Usepa - United States Environmental Protection Agency (1998) Method 3051A: microwave assisted acid digestionof sediments. US Government Printing Office, Washington. Available online at:

<http://www.epa.gov/storet/archive/modern/doc/FieldLab AnltPrcdAndEqpDetail.pdf>. (Accessed 30 january 2016).

Wang P, Qu E, Li Z, Shuman LM (1997) Fractions in availability of nickel in loessial soil amended with sewage sludge. J Environ Qual. 26:795-801.

Zornoza R, Faz A, Carmona DM, Kabas S, Martínez-Martínez S, Acosta JA (2012) Plant cover and soil biochemical properties in a mine tailing Pond Five Years After Application of Marble Wastes and Organic amendments. Pedosphere. 22:22-32. 